\title{
Development of The Abandoned Children in Building The Nation Character in Orphanages Ulul Azmi
}

\author{
Sandi Setiawan \\ Civic education \\ Universitas Pendidikan Indonesia \\ Bandung, Indonesia \\ jalankolmas@gmail.com
}

\begin{abstract}
Children are the successors of generations of a nation is generally abandoned children, especially orphans or orphans, in general, they live in the orphanage and live under the care of the orphanage. For abandoned children not just get the protection and fulfill basic needs, but need to get the assurance of growth and development in character education naturally. Therefore, this research with a qualitative method of descriptive approach. Data collection is done by observation technique, interview, and documentation. (1) process of character building in the orphanage, (2) character values implanted for orphanage children, (3) inhibiting factor and supporting child development in order to grow children character in an orphanage. The result of the research shows that the strategy of character education in Ulul Azmi orphanage can be done through integration of values and ethics in the daily activities of the orphanage based on boarding school, internalization of positive values which is cultivated by all citizens of the orphanage 24 hours, habituation, practice, an example. So, it creates a synergic atmosphere synergize between the nanny and foster care.
\end{abstract}

Keywords-abandoned child; coaching; character; orphanage

\section{INTRODUCTION}

Of the family is the smallest community of society which became the beginning of the construction of social values, religion, morals, and values of others. Starting from the family of then the values of the character of a nation can be formed, because of the smallest community is inculcated early personality values such as religious, rights and obligations, discipline, cooperation, kindness, honesty, solidarity, empathize, and other positive character. If expectations are formed from every family not built properly, then building the character of a nation which is expected above will not materialize, not all children are fortunate to get coaching from parents, there of them since small does not have a parent, so that it is not possible to provide coaching and education due to the limitations of cost, then usually the children are in orphanages.

Children are the assets of the nation's priceless, they became the successor to the struggle of the nation, but there are still many children among us who lose the attention and affection of both parents due to experience a variety of problems, so the family failing to meet the function and its role. Workhouses foster care as an alternative that replaces the function of the servant family, so the family disruption can be addressed as fully as possible, with the hope they have a bright future and better.

The orphanage is a social welfare institution responsible for providing replacement services in fulfillment of physical, mental, social and in foster care, so as to gain wider opportunities and adequate for the development his personality is as expected. Then it can be understood that the orphanage was is one vehicle for addressing the social constraints that are developing, such as education, poverty, abandoned children, victims of natural disasters, and so on. It said one vehicle for addressing social problems, because the Government in this case has not yet been able to deal with social problems as a whole more on crisis and reform in the [1]. "The family is foundation of both intellectual and moral development, helping parents to be good parents is the single most important things a school can do to help students develop strong character and succeed academically." Of these, Lickona opinion clear that grounding moral and intellectual development of the child is the family but not all children are fortunate to have a family.

In his book social issues children [2] abandoned children were the children who enter the child category prone or children who need special protection. A person is said to be displaced, not just she no longer has one or both parents. However, the displaced here also in the sense of when the rights of the child to grow and develop is reasonable, to get a decent education, and to obtain adequate health services, are not being met due to negligence, lack of understanding the inability of the parents, or deliberate action.

From the data pusdalisbang. West Java government survey found in 2011 that child stranded is known totaled 126243 people displaced children very concern things that should be a concern of government and society in accordance 1945 Article 34 Paragraph 1 which reads Poverty and child - neglected children maintained by state in article 55 (3) of RI Law No.23 Years. 2002 explained that the connection with the implementation of maintenance and care of abandoned children, government agencies and public institutions, as referred to in paragraph (2) can be entered into a collaboration with the various parties concerned. The orphanage is defined as a house, place or residence used to care for orphans, orphans and orphans [3]. 
It is said that family conditions affect the child's condition, because problems occur in the family, the child is experiencing anxiety and the condition makes them different to the conditions finally family conditions without problems. Another problem that is neglected in children is not all children are in the functioning of the environment in their lives due to deliberate action or state of the title.

\section{THEORY REVIEW}

Coaching is all the efforts and activities pertaining to planning, organizing, financing and coordination of the implementation of the program of preparation of oversight work effectively and efficiently to achieving goals with results that make the. Based on the above opinion, then it can be inferred that coaching is the business, process, or activity which includes planning, implementation to evaluation conducted extensively through the organizational elements such as regulatory or policy, organizers of the workers, staff and implementers, materials and tools (material), and other devices are cost effective and efficient way to achieve the goal, good results as well as the maximum. To make the students have a good moral or character requires the construction of a continuous and sustainable improvement. To realize the lofty commendable behavior protégé is not easy because it concerned the habits of life. The training will be successful only with great effort and patience as well as the support of parents and the community.

Abandoned children according to the Social Department [4] as follows: the characteristics of abandoned children are orphans, orphan, orphan abandoned 0-21 years, abandoned children who have experienced a split so that the child could not grow a flower in reasonably good physical, spiritual, and social events, abandoned children whose families could not afford to carry out functions and social role reasonably.

Based on some of the above definition, then it can be inferred that the waif is a State in which the child's needs are not being met basically good physical, mental, spiritual, social and do not have the opportunity to grow and develop as well as carry out the function of its social role reasonably. That question is the abandoned children orphans, orphan, orphans, abandoned children from families not able, children dropped out of school aged 0 years to 21 years and unmarried.

Character education according to the philosopher Michael Novak in Thomas's book [5] is a compatible mixture of all the good that is identified by religious traditions, literary stories, sages, and intelligent people in history. So the characters that exist in human beings do not all have the good from within themselves but many factors are more and less because human development is essentially in an earlier culture that has decreased in a way that causes a human habit to perform habitual actions.

According to [6] character education contains three principal elements, namely know kindness (knowing the good), loving kindness (loving the good), and do good (doing the good). Character education is not merely teaching which are true and which ones are wrong to learners, but more than that character education instilling the habit (habituation) of good so that learners understand, be able to feel, and want to doing good. So, character education brings the same mission with morals or education of moral education

According to [7], 18 values of national character have been identified that need to be instilled in students from Religion, Pancasila, Culture and National Education Objectives. The eighteen values are (1) religious, (2) honest, (3) tolerance, (4) discipline, (5) hard work, (6) creative, (7) independent, (8) democratic, (9) feeling of wanting know, (10) national spirit, (11) patriotism, (12) respect for achievement, (13) friendly / communicative, (14) love of peace, (15) love of reading, (16) care for the environment, (17) care social, (18) responsibility The implementation of character education is one thing that is multitask done at any level of education. This is very reasonable because education is the main foundation for the growth of Indonesia's young generation.

Guidance value of the child character in ulul azmi orphanage based on boarding school education to form a child into an individual who has good character in accordance with the teachings of Islam. Foster children in the orphanage itself has a variety of characters who initially did not have a good character education guidance. Children who enter the world of orphanage-based boarding school will be familiar and formed a good character according to the teachings of Islam and the norms of the Indonesian nation.

The construction of the faith is often aligned with fostering the values of trust, so that the value of that trust is the most important value and first in life, value is seen as something that has a price of higher position, for example, the value of the faith is something most underlie all life. With a faith that is applied in everyday life will bear the student at traditional Muslim are honest, reliable, discipline, responsibility, cooperation, tolerant, independent, polite, friendly, and civility. The value of the example is a method that is most potent in internalize values in boarding school, because the value of the example was taken from the example of Prophet Muhammad.

\section{METHODS}

Type of this research is a descriptive qualitative research to uncover the strategy and implementation of character education data collection Techniques used in this research is the interview, observation, and documentation. The interview is used to capture data or information relating to a range of policies undertaken in the implementation of character education school discipline. The observation is done to look at the implementation of character education discipline, refraction through everyday life of foster care. Engineering documentation used to obtain data about the conduct of daily schedules and foster care are made by Superintendent Parlors.

To obtain data that can be accounted for scientifically, in this study an examination of the validity of the data was carried out. In this study, the validity of data checking techniques used is triangulation techniques, namely the technique of crossing information obtained from various sources and sources [8]. Triangulation techniques are carried out by method triangulation, which is by re-checking information on the results of interviews with documentation and observation. 


\section{RESULTS AND DISCUSSION}

Character education strategies can be implemented by several approaches that include: (1) integrating values and ethics on subjects; (2) internalization of the positive value that all orphanage residents have been cultivated; (3) habituation and practice; (4) modeling and modeling; (5) the creation of a character atmosphere in an orphanage; and (6) refraction or culture. In an effort to improve the suitability and quality of character education, the National Ministries of Education developed the Grand Design character education for every path, ladder, and type of educational unit. Based on the developed grand design [9], the psychology and social culture of character building in the individual is a function of all human potential (cognitive, affective, conative, and psychomotor) in the context of cultural social interaction (in family, and society) and lasts for life.

Grand design becomes the conceptual and operational reference of development, implementation, and assessment on every path and level of education. Configuration of character in the context of the totality of psychological and social processes is categorized into: (1) if the heart (spiritual and emotional development); (2) intellectual development; (3) sports and kinesthetic development (physical and kinesthetic development); and (4) affection and creativity development. The four psychosocial processes are integrated and related to each other, which leads to the formation of characters that become the embodiment of noble values. The development and implementation of character education needs to be done with reference to the grand design

Implementation that is emphasized at the Ululazmi Orphanage coaching the character value into individuals who have good character in accordance with the teachings of Islam, in fact instill the child's character value requires a mature concept so that children can receive and reflect on the selfeducation provided by the caregiver. As per the results of the study shows the concept of character values. First, the creation of a characteristic culture is vertical. Second, the creation of a characterized culture that is horizontal. This is done by establishing the home as a social intuition which, when viewed from the structure of its interconnectedness, can be classified into three relationships, namely: (1) subordinate boss relationships; (2) professional relationship; and (3) an equal or voluntary relationship based on positive values, such as brotherhood, generosity, honesty, mutual respect, and so forth.

\section{A. Findings Researchers Have 12 Characters Implementation Implemented in Proses Character Building Children Orphanage Ulul Azmi}

- The construction of the religious character of the orphanage Ulul Azmi inculcate religion by way of using the newfangled education boarding schools. In stressing education orphanage that is upholding the teachings of Caregivers also familiarize foster care to keep religious values in regard they are holding from birth until now, because with the religious education of their personality is formed well according to Islamic Sharia.
- Honest character development: Efforts in getting children to behave honest caregivers provide an example of how to be role models and charismatic caregivers for children and stimulate children, so children do not feel in the robot who always made ruled and forced in doing all activities. Honest attitude should be given a child from an early age because honest is the foundation that must be cultivated in a person for a better life.

- Character building guidance Caregiver attempts are: (1) shake hands with all guest and foster children when they want to do activities within the orphanage; (2) are taught to always be happy to help despite different religions; (3) guiding foster children to always appreciate friends; (4) facilitating foster children to obtain the same learning experience.

- Disciplinary character of efforts: (1) get up early and pray in congregation in a timely manner; (2) impose sanctions for violating the ordinance of the orphanage; (3) provide an example to dress neatly and politely according to Islamic sharia; (4) installing the rules that are easy to read by foster children; (5) invite foster children to use the best time possible; (6) facilitate students to study learn about maintaining the order of the orphanage.

- Character building of hard work attitude: caregiver effort (1) create learning atmosphere in orphanage in a fun way; (2) create a competitive atmosphere; (3) putting up a slogan about studying hard and working hard; (4) be an example to carry out the task in earnest; (5) facilitating foster children to always complete the task well.

- Innovative / credible character building: (1) following the hadrooh, solawat and calligraphy contests, providing a place for foster children to express their talents, interests, and desires; (2) facilitating foster children to make handicrafts such as sewing, calligraphy, automotive; (3) decorate the orphanage environment to be clean and beautiful.

- Construction of self-contained character: (1) familiarize the foster care to always learn in all lessons; (2) facilitate the foster care to follow the cooking activities in orphanages; (3) facilitate the foster care to always work on a task or task tasks both orphanage individually.

- Cultivation of curiosity characters: (1) providing various information through print or electronic media; (2) facilitating foster children in activities that may invite curiosity.

- Development of the character of the spirit of nationalism: (1) follow ceremonial activities in their respective school environments, (2) posting photos of presidents and representatives along with the eagle emblem; (3) a lecture on nationalism in Islam; (4) To read manakib / biography of the scholars in the 
struggle to liberate the state of Indonesia; (5) Sing a national song.

- Guidance of love character of the homeland; (1) ceremonies every Monday and Monday in the school environment, (2) set an example to follow ceremonial activities or activities on Monday and national holidays, (3) posting photos of presidents, vice presidents, country flags, national emblems and cultures Indonesia, (4) implements it into the life of the community.

- Guiding democracy in foster children: (1) providing suggestion boxes and complaints; (2) implement learning in the orphanage environment into the community environment; (3) to respect the opinions of others who differ.

- Fostering a sense of responsibility: (1) facilitating foster children to lead prayer when they start learning the boarding school in the orphanage; (2) facilitating foster children to carry out picket tasks according to their schedule; (3) set an example to carry out the tasks according to their obligations; (4) stick to the discipline easy to read by foster children.

\section{B. Obstacle Factors and Supporting Factors Development Values Characters of Foster Care}

1) Obstacle factor: The inhibiting factor in educating foster children in the Ulul Azmi orphanage is the inhibiting factor, since not all foster children are the educating environment of their character, but in fact everyone has a good character but an environment that can change it. So in the orphanage environment is trying to provide the process of care for children with good character.

2) Supporting factors: The Ululazmi Orphanage is an orphanage that guides and educates the less fortunate foster children of orphans, orphans, orphans and orphans, and the poor. Foster children feel comfortable and very comfortable living in an orphanage environment that sneaked the cottage.

Pesantren, by following the activities in Ulul Azmi orphanage to get the science of religious education in depth and character education is complex. In providing education the caregiver character is very concerned about what is in need of foster children.

\section{CONCLUSION}

Implementation of character education in the nation's orphanages Ulul Azmi has been running quite effective, where the values of the quantity of characters not only taught but is also applied in the daily lives of abandoned children in an orphanage. The process of implementation in the orphanage are integrated through some process phases, namely:

- The process of refraction is done by introduced da teach values through teaching and discipline.

- the process of

- Founding do apply these into the daily activities of value children with exemplary of teachers, builders in the orphanage.

- The stage of establishing the development implemented by giving responsibility to the foster care to carry out their duties and in the establishment of the child already removed to independently perform activities of appropriate values taught.

Restricting Factor in instilling character foster care there are 2 factors institutions due to inadequate infrastructure as supporters and origins of child foster care do not come from an environment that abandoned children make less got development education character early on, habits in their neighborhood are less supportive of the existence of the character education caused their children orphans, underprivileged or orphaned, and strays.

\section{REFERENCES}

[1] T. Lickona and M. Davidson, Smart \& Good High School: Integrating Excellence and Ethics for Success in Schools, Work, and Beyond. Cortland: Center for, 2004.

[2] B. Suyanto, Masalah Sosial Anak Revisi. Jakarta: Kencana, 2012.

[3] W. Poerwadarminta, Kamus Umum Bahasa Indonesia. Jakarta: Departemen Pendidikan Nasional, 2013.

[4] Depsos RI, Pedoman Penyelenggaraan Pembinaaan Kesejahteraan Sosial Anak Melalui Panti Sosial Asuhan Anak. Jakarta: Departemen Sosial RI, 1995.

[5] T. Lickona, Educating for Character: How Our Schools can Teach Respect and Responsibility, New York: Bantam Books, 1991.

[6] M. Marzuki, "Revitalisasi Pendidikan Agama di Sekolah dalam Pembangunan Karakter Bangsa di Masa Depan”, Jurnal Pendidikan Karakter. 3 (1), pp. 64-76, 2013

[7] Kemendiknas, Pembinaan Pendidikan Karakter di Sekolah Menengah Pertama. Jakarta: Departemen Pendidikan Nasional, 2010.

[8] S. Sugiyono, Memahami Penelitian Kualitatif. Bandung: CV. Alphabeta, 2012.

[9] Kemendiknas, Pengembangan Budaya dan Karakter Bangsa, Jakarta: pusat kurikulum dan perbukuan, 2010. 